\title{
Study of South African small retail businesses' utilisation of information resources
}

\author{
H-J. Chen \\ Centre for Information and Knowledge Management \\ University of J ohannesburg \\ Johannesburg, South Africa

\section{Rensleigh *} \\ Centre for Information and Knowledge Management
}

\author{
University of J ohannesburg \\ Johannesburg, South Africa \\ crensleigh@uj.ac.za
}

Throughout the world one finds that small businesses are playing critical roles in absorbing labour, penetrating new markets, and promoting entrepreneurial and innovative activities. These businesses have the same information needs as their bigger counterparts. Web portals can offer small businesses platforms to reach information resources effectively and hence create a stimulating business community for entrepreneurship. The purpose of this research was to investigate the extent to which online community information portals can promote the use of information resources for small retail business in South Africa. For the empirical part of this research 150 questionnaires were completed by small retail businesses. The questionnaire consisted of four sections: business biographical information; business information and agencies; information and communication technologies usage; and community and portal activities. It was found that small business owners and managers are unwilling to disclose business information, especially their financial information but that they are very interested in networking with other businesses, in particular with potential customers and suppliers.

Key words: Small business, retail, information resources, online community

Received 19 J une 2009

\section{Contents}

1. Introduction 1.1 Research problem

2. Rationale of the study

3. Research approach and methodology

4. Empirical findings

4.1 Business biographical information (Section A)

4.2 Business information and agencies (Section B)

4.3 I nformation and communication technologies usages (Section C)

4.4 Community and portal activities (Section D)

4.5 Cross tabulation

5. Conclusion

6. References

\section{Introduction}

The information economy is one that relies on knowledge and information rather than labour and 
capital, that is, the economy is shifting from being capital-driven to being information-driven. One of the main causes of the new competitive landscape for business is the changes in information and communication technologies (ICTs) (De Bruyn 2003:4). ICTs do not only change the rules in the information and telecommunication industries, they also influence future developments and business competitiveness in all business sizes across all industries.

The ability to successfully transform information resources into knowledge, that is, to maximise the value of knowledge, is the new challenge in achieving a sustainable competitive advantage (Bogdanowic and Bailey 2002). Throughout the world one finds that small businesses are playing critical roles in absorbing labour, penetrating new markets, and promoting entrepreneurial and innovative activities. They are especially important to South Africa as small businesses also provide refuge for the impoverished and the unemployed (Baumol 2006).

Small businesses have the same information needs as their bigger counterparts, but they are usually in a disadvantaged information position in terms of finance and expertise. This article reports on research done for a Master's degree (Chen and Rensleigh 2008) with regard to the usage of business information and ICTs among small retail business owners and managers in South Africa.

top

\subsection{Research problem}

The research problem for this study is found in the literature that shows there are so many online information resources available, yet it seems that many small businesses do not know how and where they can meet to find and share information for better decision making. The following research question was formulated for this study:

To what extend can online community information portals promote the use of information resources for small retail business in South Africa?

\section{Rationale of the study}

Small businesses provide a possible solution to South Africa's high level of unemployment and contribute to sustainable socio-economic development (Kubheka 2006). Web portals offer small businesses platforms to reach information resources effectively and hence create a stimulating business community for South African entrepreneurs. For this reason, it is a worthwhile exercise to establish the extent to which Web portals and other ICTs could be utilised in this pursuit.

The theoretical departure for this study is based on the work of Uzokwelu and Gunnarsdottir (2001). According to Uzokwelu, the concept of online communities is basically used to refer to an online environment where all kinds of people come together to do any, some or all of the following activities:

- Exchange information and ideas

- Share common interests

- Entertain each other

- Seek different kinds of help

$\square$ Offer support to one another

- Trade goods and services

- Foster relationships.

On the other hand, small businesses' competitiveness lies in being dynamic and flexible. These features are vital in the age of 'lean consumption', that is, knowing what customers want and providing what is wanted where it is wanted and exactly when it is wanted (Womack and Jones 2005:61). Small businesses have the same needs as their larger counterparts to be informed about market trends, technology developments and new techniques to remain competitive. Such information resources enable small businesses to react faster (dynamic) and adapt better (flexible) to changing global markets.

Small business owners and managers need business networking and information resources for better decision making. These can be achieved with online community information portals. The research 
findings of this study should offer all stakeholders in small business development in South Africa, including governments, industries and academics, a better understanding and guidelines for delivering the best possible information resources to small business owners and managers and for designing inforrmation portals.

\section{Research approach and methodology}

The research approach that was followed for this study can be classified under Pasteur's quadrant of Stokes' Research Classification Quadrants (1997), namely 'user-inspired basic research'. This type of research is devoted to solving problems in order to improve people's lives and is, therefore, deemed the ultimate research type, considered to be inspired by both the quest for fundamental understanding and consideration of use.

An extensive literature study was undertaken to establish the theoretical foundation for addressing the research problem. Quantitative research in the form of a questionnaire survey was conducted among owners and managers of small businesses in the retail industry to determine their information resources and requirements for service.

The questionnaire was compiled based on literature studies to determine small businesses' adoption of ICTs, information requirements and attitudes to sharing of business information. The questionnaire consisted of four sections, namely Section A: Business biographical information, Section B: Business information and agencies, Section C: Information and communication technologies usage, and Section D: Community and portal activities. Mainly close-ended questions were included in the questionnaire, with scaled options from which respondents could select the most appropriate alternatives.

The sampling method used in this research project was convenience sampling. Major shopping centres in five sections of the greater J ohannesburg metropolitan area were visited for this survey, namely J ohannesburg Central Business District (CBD), East Rand, West Rand, northern suburbs and southern suburbs. Only non-franchised individual retail stores in shopping centres or shopping complexes were visited and their owners or managers were asked to fill in questionnaires. Thirty questionnaires were completed for each area and a total of 150 questionnaires were used for the statistical analysis of this research.

top

\section{Empirical findings}

The questionnaire consisted of four sections. The following is a discussion of some of the findings in each of the sections.

\subsection{Business biographical information (Section A)}

Most of the businesses visited traded in textiles, clothing, footwear and leather goods $(39 \%)$, followed by specialised stores (13\%) and stores specialising in food, beverages and tobacco (10\%) (Figure 1 ). In terms of the age of the business, most of the business owners and managers interviewed had been trading for over ten years ( $42 \%)$, followed by the group trading for between one and three years (21\%) and the one trading for five to ten years (19\%).o:p>

Figure 1 Result of question 2: Business type 


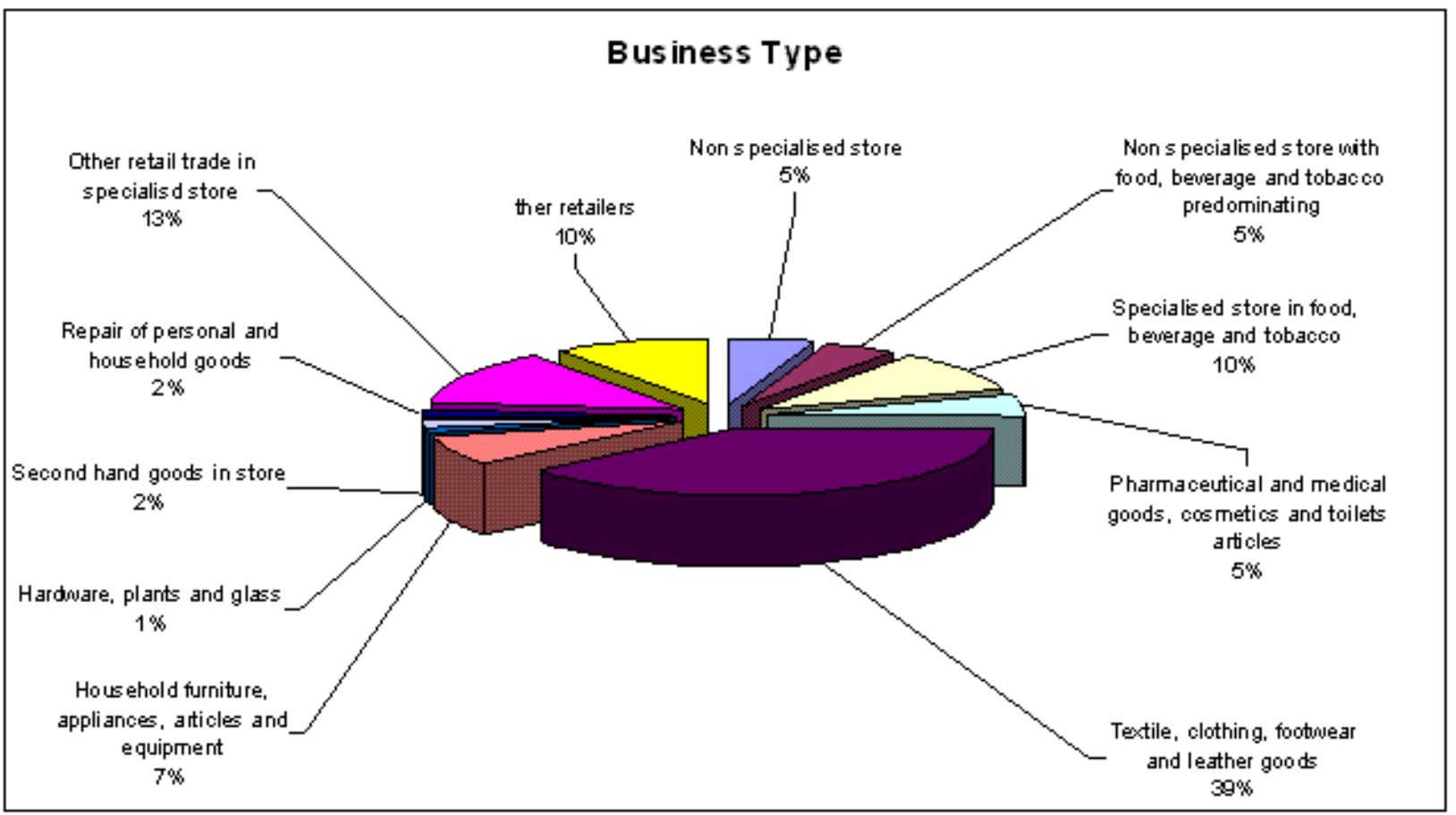

Half $(50 \%)$ of the business owners and managers' home language was English, $11 \%$ of the respondents' home language was Zulu and $9 \%$ of them were Afrikaans. A significant percentage (13\%) of the respondents' home languages were not any of the 11 South African official languages. Although the home languages were diversified, almost all respondents (98\%) preferred English as the language for business communication.

The number of employees in these small businesses was small: $63 \%$ of the respondents had five or fewer full-time employees, $27 \%$ had six to ten, $6 \%$ had 11 to 25 and only $3 \%$ had 26 to 50 full-time employees. One per cent of the small businesses indicated that they had over 100 full-time employees (Figure 2).

Figure 2 Result of question 7 Number of full-time employees

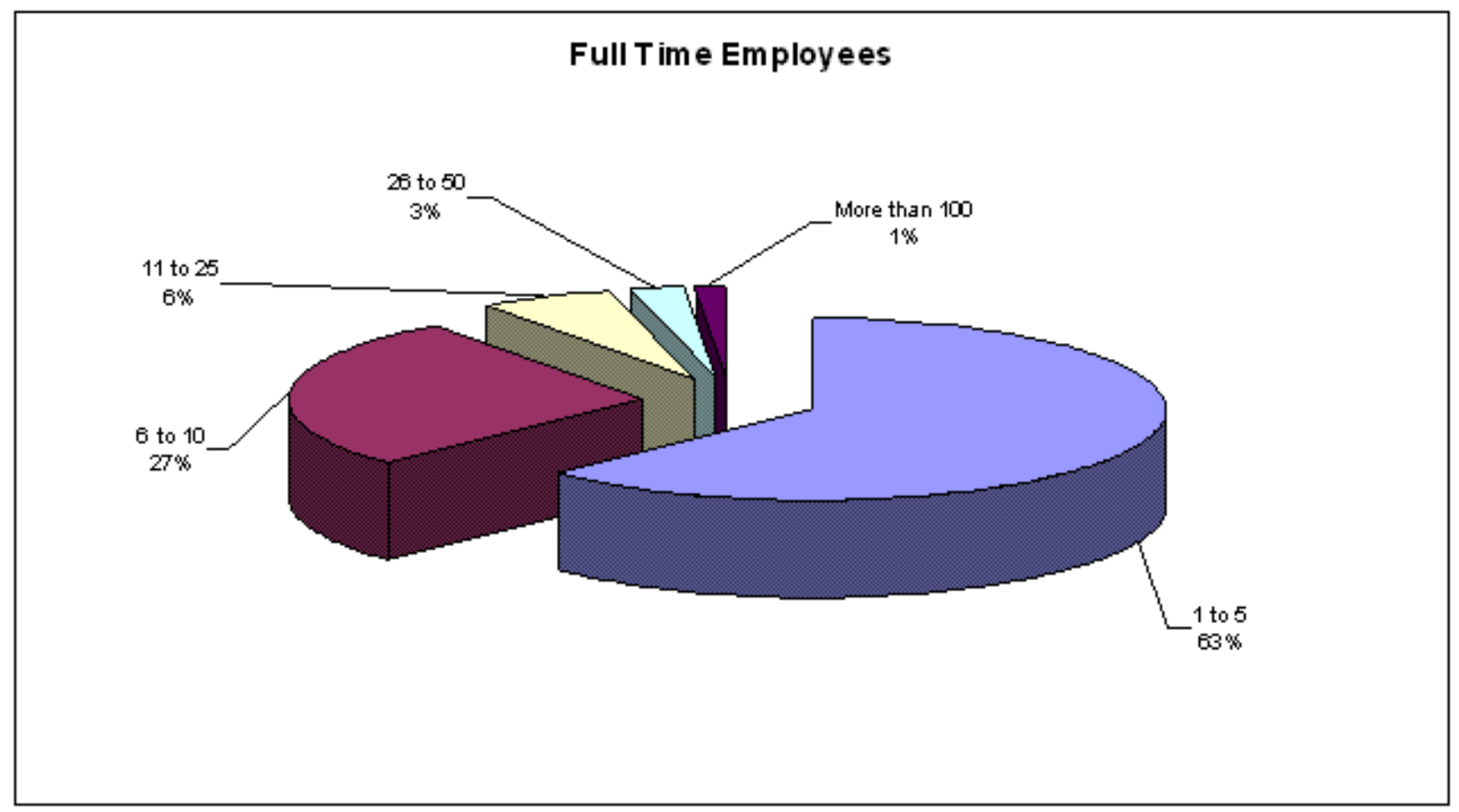

The average annual business turnover also varied. Although $21 \%$ of the respondents had an annual turnover of over 3 million rand, there were $15 \%$ of the respondents who had an annual turnover of 
between 0.5 million and 1 million rand, $13 \%$ who had a turnover of between 2 million and 3 million, and $13 \%$ who had a turnover of between 400000 to 500000 rand.

top

\subsection{Business information and agencies (Section B)}

Attitudes to and use of business information and small business development agencies, internal business information (manufacturing, finance, marketing, human resources and information technologies) received higher priority compared to external business information (industrial, globalisation, social, ecological or environment, political and legal and economic information).

In terms of internal business information (Figure 3), most business owners and managers (59\%) considered finance and marketing information to be 'important' or 'very important'. However, it was noticed that $9 \%$ of the respondents regarded information technologies as 'not important' to their businesses. In contrast, only 3\% considered marketing information 'not important' and 4\% considered financial information 'not important'.

Figure 3 Result of question 10: Importance of internal business information

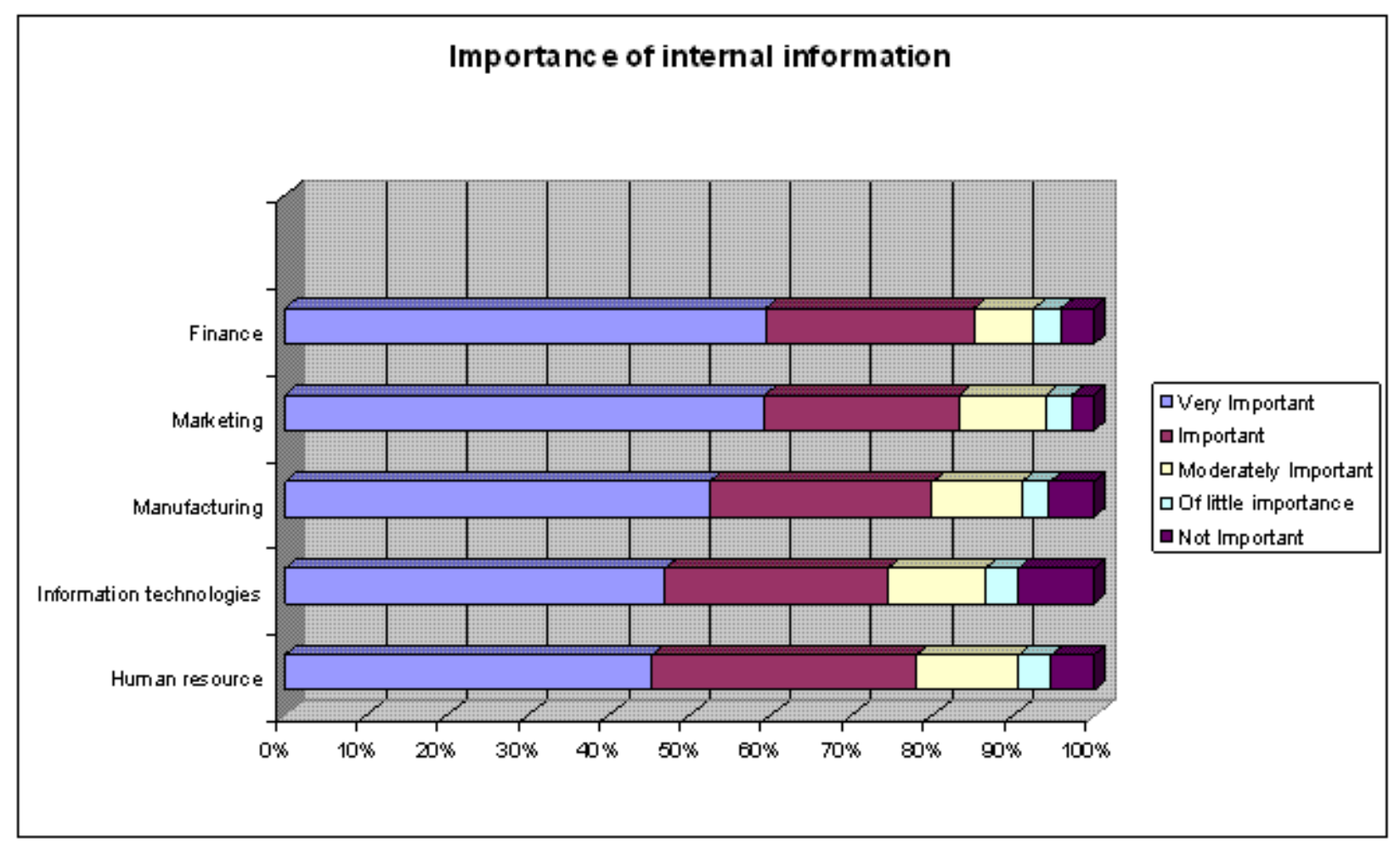

In terms of external business information (Figure 4 ), most respondents (55\%) regarded economic information as 'very important' to their businesses, followed by industrial information ( $44 \%)$. In contrast, globalisation, social, political and ecological or environmental information was considered to be less important, with respectively $24 \%$ and $20 \%$ of the respondents regarding globalisation and ecological and environmental information as 'not important' to their businesses.

Figure 4 Result of question 11: Importance of external business information 


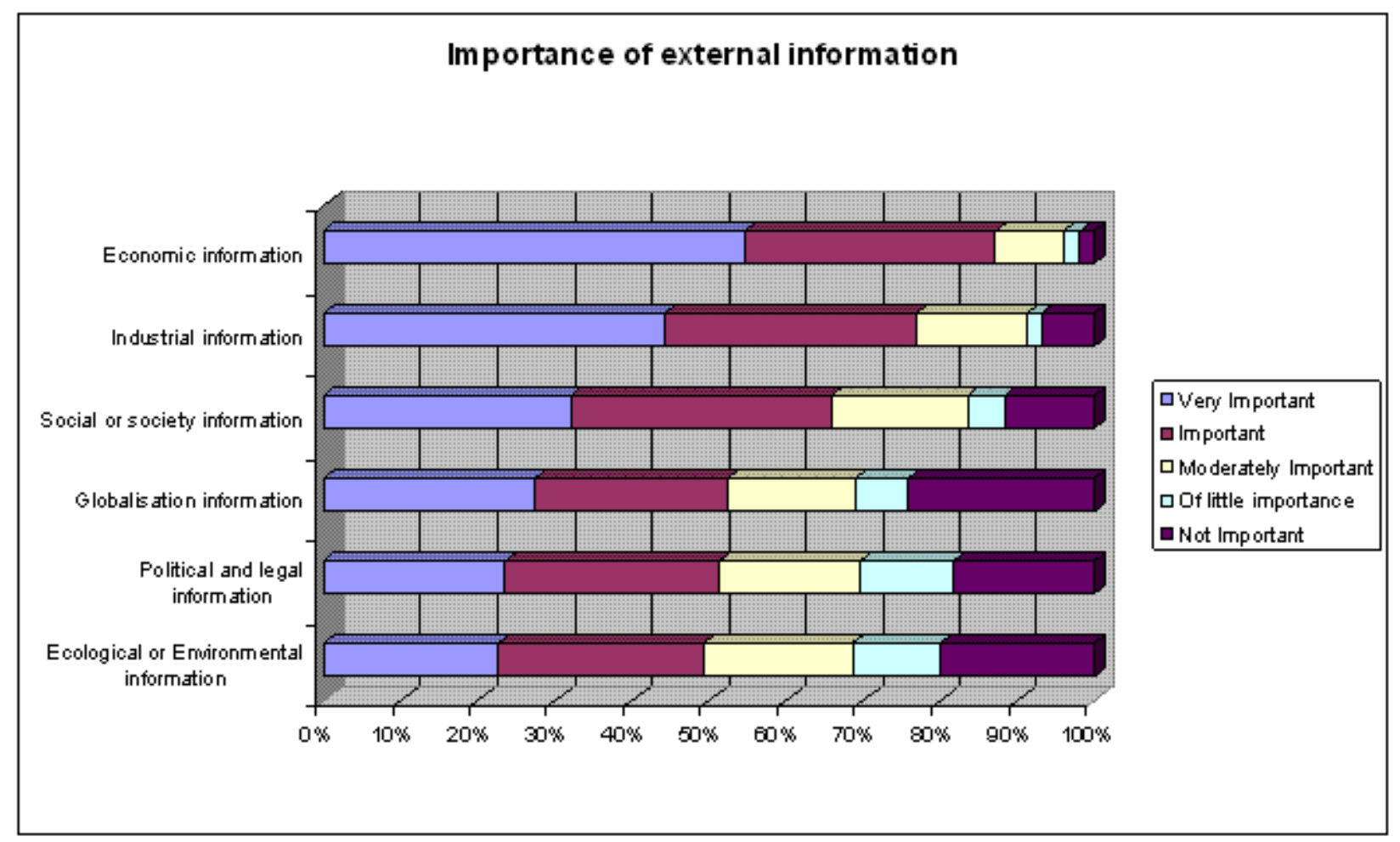

With regard to the source of information (Figure 5), traditional media such as newspapers, magazines, television and radio were still the primary sources of information for small business owners and managers. Online information sources and industrial organisations were not yet regarded as important sources of information for small businesses. Only $27 \%$ of those interviewed considered online newspapers and magazines as very important and $19 \%$ considered professional or industrial organisations as a very important source of information.

Figure 5 Result of question 12: Importance of information sources

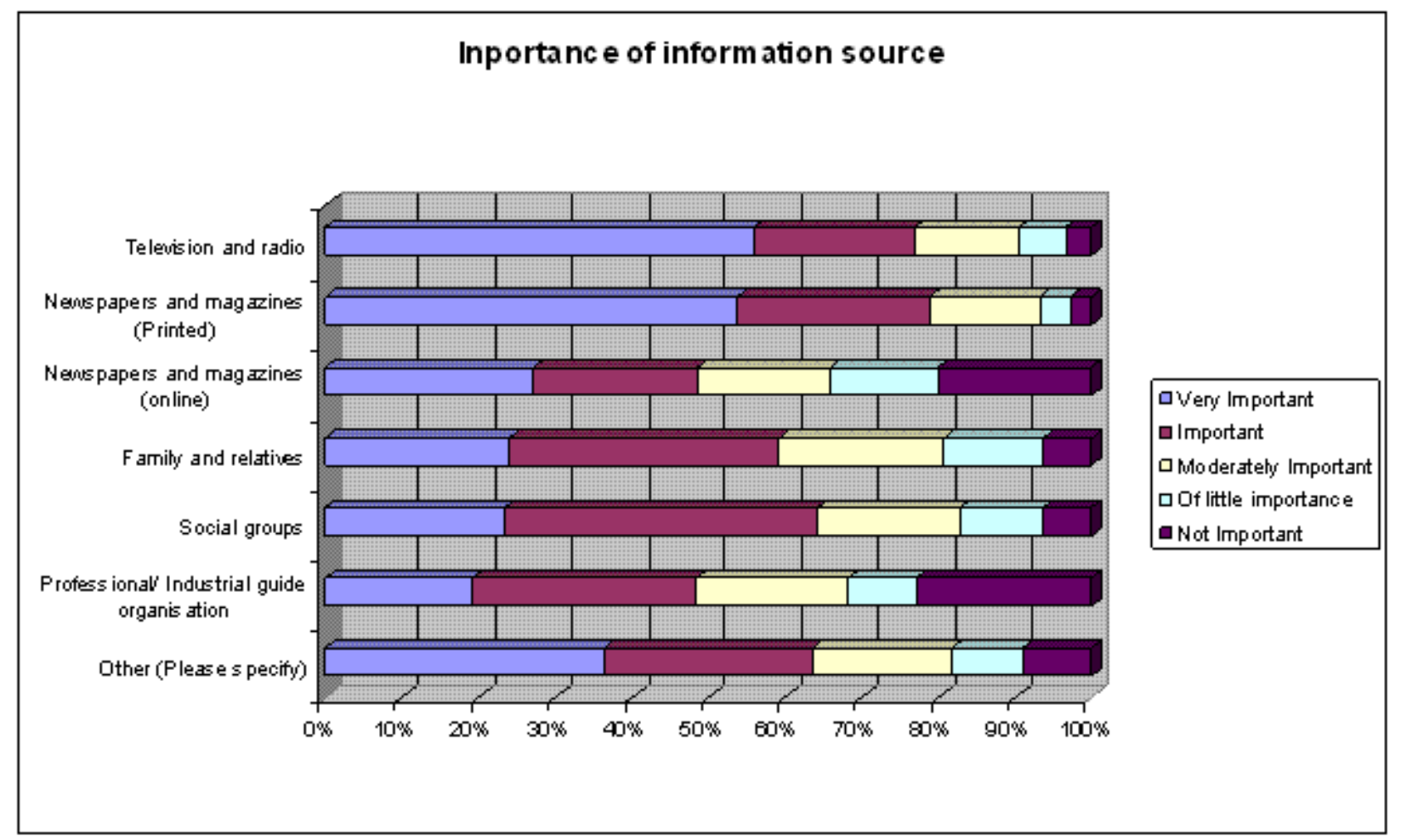

There are many small business development agencies in South Africa. However, only a few of the small business owners and managers knew about them and even fewer had actually made use of them. This was true especially of government-funded agencies. Half of the respondents (50\%) knew about business partner mentors in banks and 19\% had actually made use of them (result of question 
13).

The responses to the previous questions indicated that small business owners and managers regarded finance as the most important aspect of their businesses. The South African government had set up various agencies dedicated to assist small businesses to obtain finance, such as the NEF, Khula Enterprise Finance Limited and SAMAF. The survey results indicate that these agencies were not known to small business owners and managers, and their usage rate was very low. This echoes the literature review done on small business development agencies. Better-known agencies were the ones set up by banks, media and universities. It is critical for government agencies to re-evaluate and design the National Small Business Strategy (NSBS).

Small business owners and managers were further asked what kind of business information they were interested in. The results indicate that access to finance (55\%), business development services $(46 \%)$ and skills development (45\%) attracted the most interest (result of question 14$)$.

Small business owners and managers were aware of the importance of business information. The results show that the government was correct in dedicating most developmental agencies in assisting small businesses to gain finance. Since the direction is correct, the government should be looking to improve the efficiency in service delivery to small businesses in South Africa.

\subsection{Information and communication technologies usages (Section C)}

With regard to the use of ICTs (Figure 6), South African small businesses were surprisingly well connected: $99 \%$ of the respondents used land-line telephones, $96 \%$ used fax machines and $91 \%$ used cell phones.

Figure 6 Result of question 15: Use of communication technologies

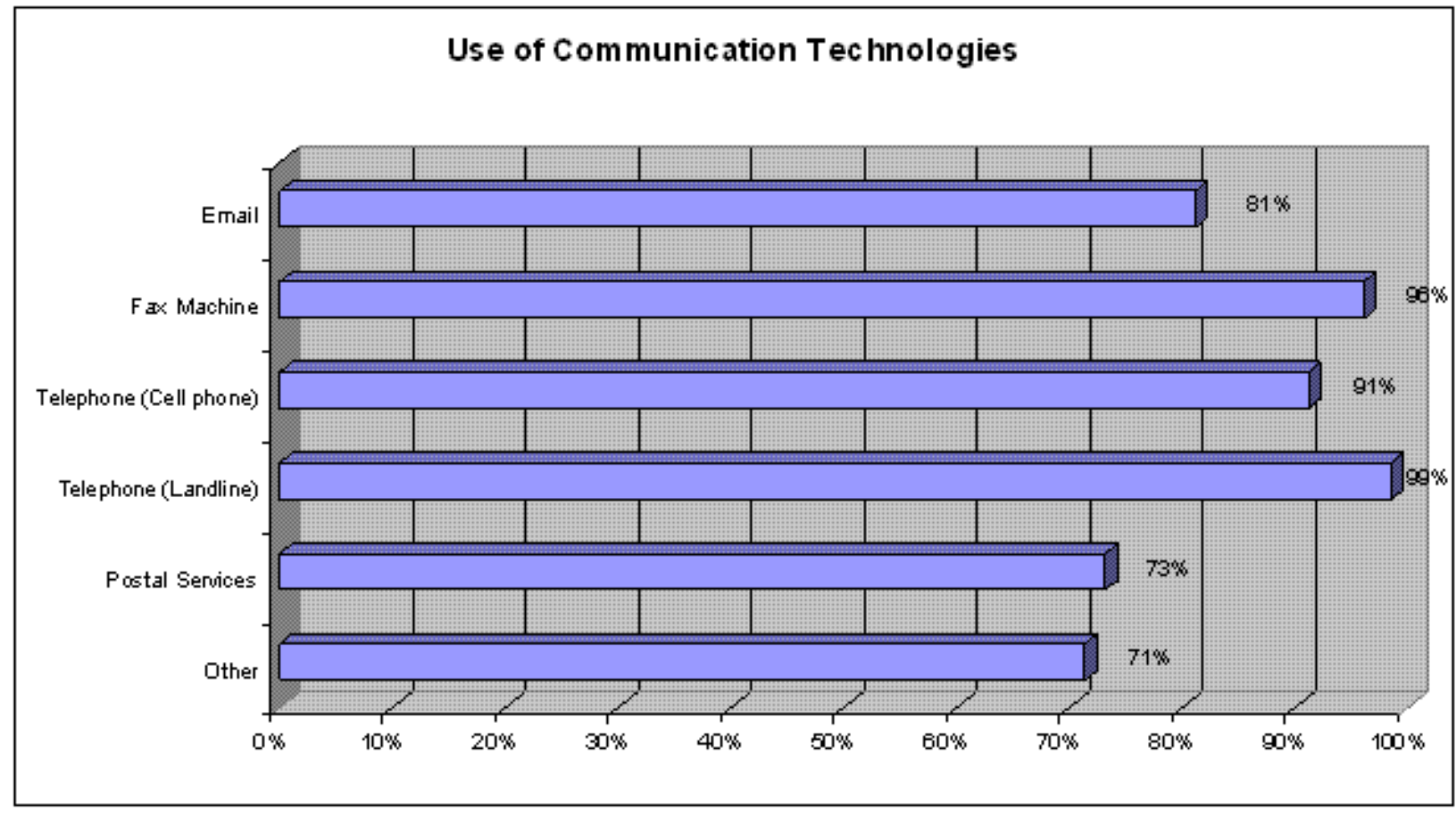

Although $81 \%$ of the respondents indicated they used e-mail, only $29 \%$ indicated that they accessed the Web more than once a day from work and only $19 \%$ accessed the Web more than once a day from home.

The survey results reflect that Internet media were not the main source of information for South African small business owners and managers. The small businesses surveyed were $99 \%$ connected to a telephone line, compared to $32 \%$ for the Gauteng population and $24 \%$ for South Africa (Statistics SA 2003). Basic Internet access could be granted with a telephone line. The infrastructure for small businesses in South Africa was in place, but it seems that access to the Web was limited.

In terms of business Web usage, they spent time on the Web mostly for e-mail (31\%), conducting e- 
commerce (18\%) and conducting information searches (16\%). Only $13 \%$ of the respondents accessed the Web for electronic newspapers or magazines more than once a day, and only $10 \%$ conducted social networking more than once a day.

Most respondents did not know about Wikis (72\%), RSS (70\%), blogging (58\%), podcasting (57\%) or VolP (55\%). The tools used most often were e-mail (34\%) and SMS (26\%) (Figure 7).

Figure 7 Result of question 19: Use of information technologies

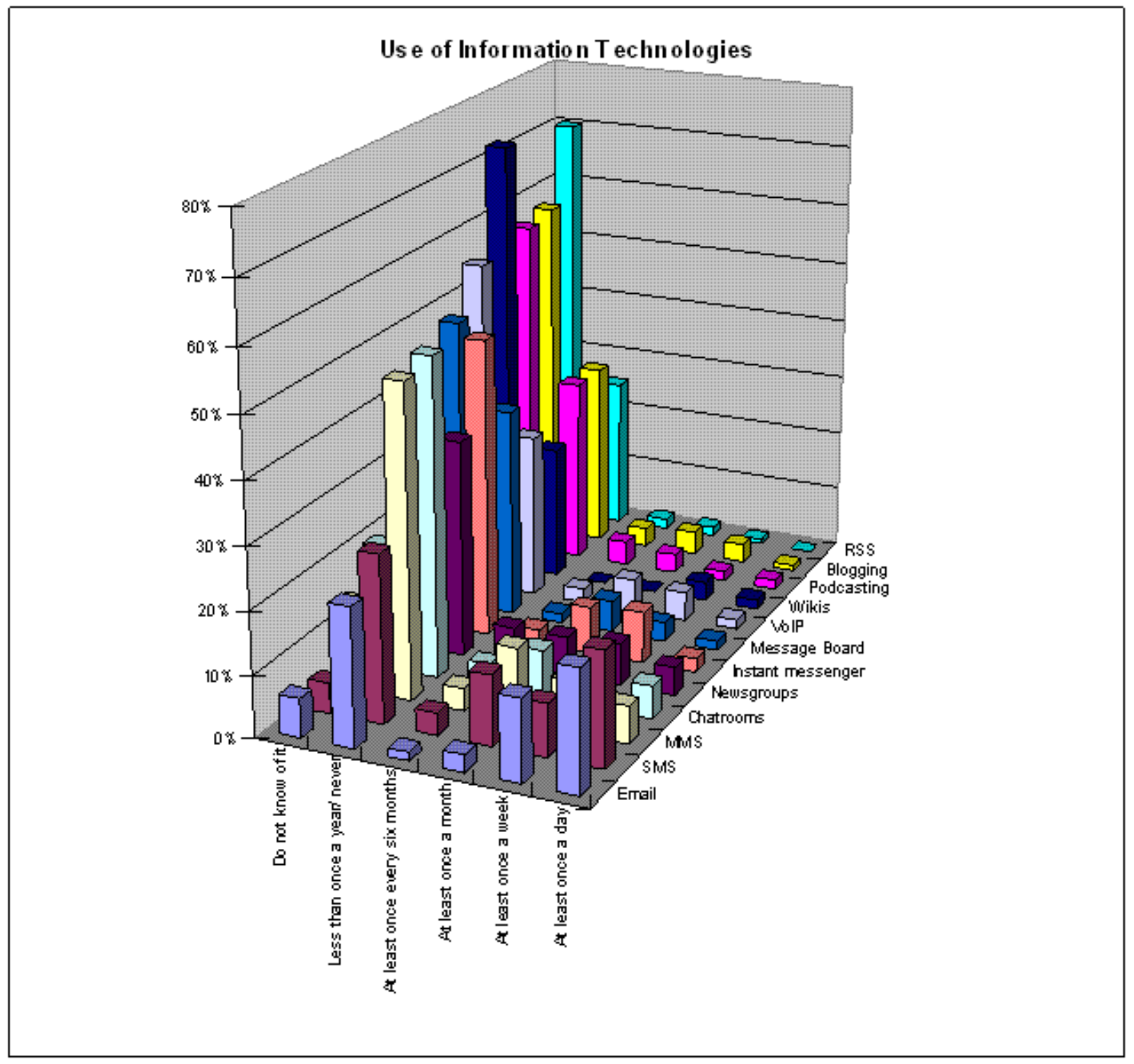

It is evident that although the Internet infrastructure was already in place for small businesses in South Africa, small business owners and managers had not adapted well to these technologies. The usage of ICTs among small businesses was still at an early stage of development where only basic tools were used.

Introducing new ICTs has a ripple effect. It is not just about computer literacy and Internet skills. Business owners and managers need to be more informed about digital information resources on the Web and the benefits of adopting information technologies.

top

\subsection{Community and portal activities (Section D)}

The responses to question 20 show small business owners and managers' attitudes toward disclosing (sharing) information (Figure 8). The responses indicate that they were most unwilling to disclose information concerning their finance and sales figures: $66 \%$ of the respondents would disclose their 
sales figures 'to no extend' and $62 \%$ would disclose their financial information 'to no extend'.

In all other types of business information, small business owners and managers' attitudes to disclosing information were mixed. Although the trend was quite negative about disclosing their business information, there was still a fairly high proportion of small businesses (ranging from $20 \%$ to $30 \%$ ) that were willing to disclose information 'to a moderate extent'.

Figure 8 Result of question 20: Attitude in information sharing

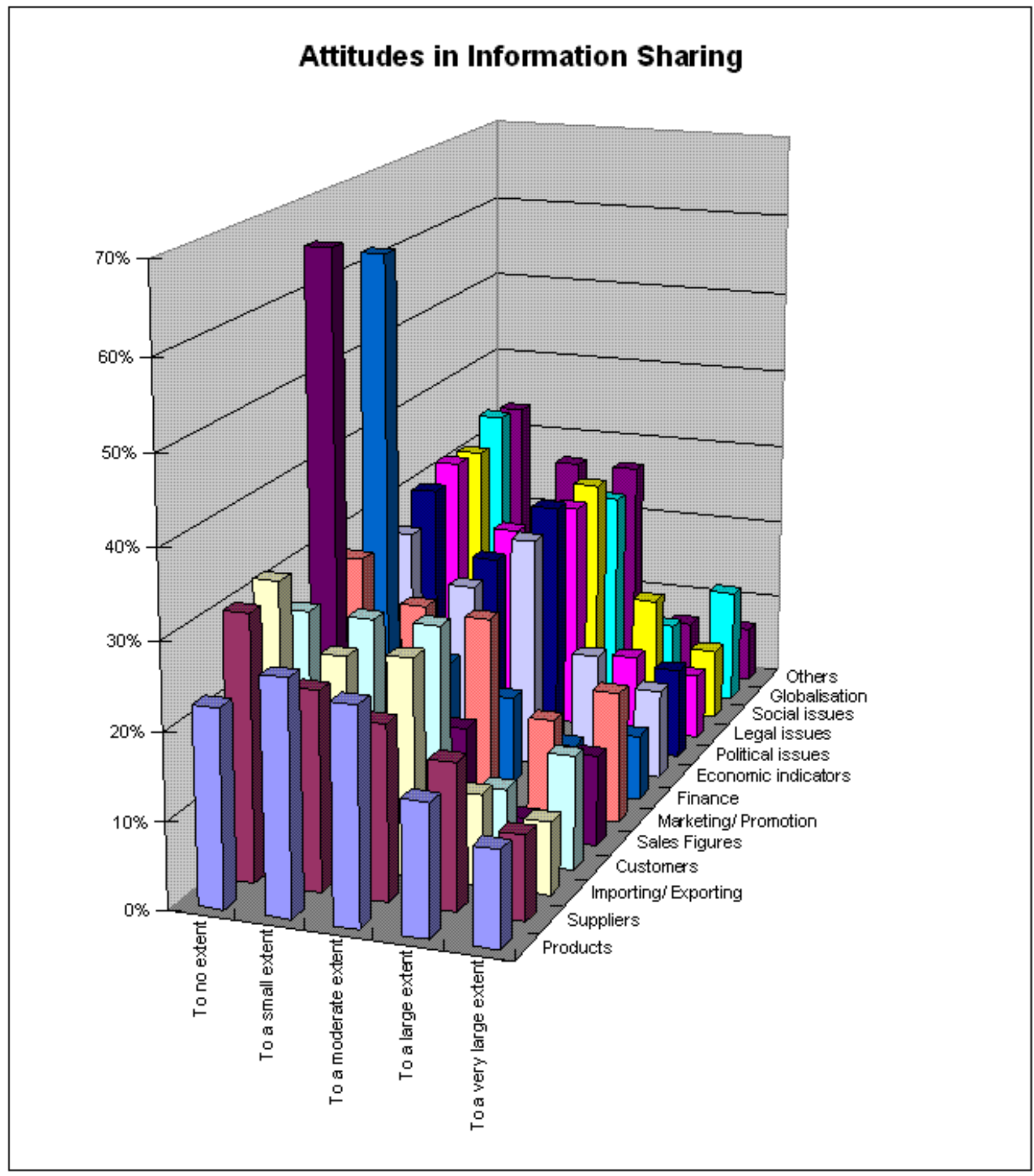

It is interesting to note that the small business owners and managers' attitude was very positive when asked if they were interested in networking with other businesses (Figure 9). Almost all respondents would have liked to network with potential customers (95\%) and potential suppliers $(91 \%)$. Most respondents would have liked to network with other small businesses for collective business activities (67\%) and other retail businesses that sell different products (65\%). Even $57 \%$ would have liked to network with other retail businesses that sell the same or similar products, and $49 \%$ would have liked to network with other businesses that were not in the retail industry. 
Figure 9 Result of question 21: Interests in business networking

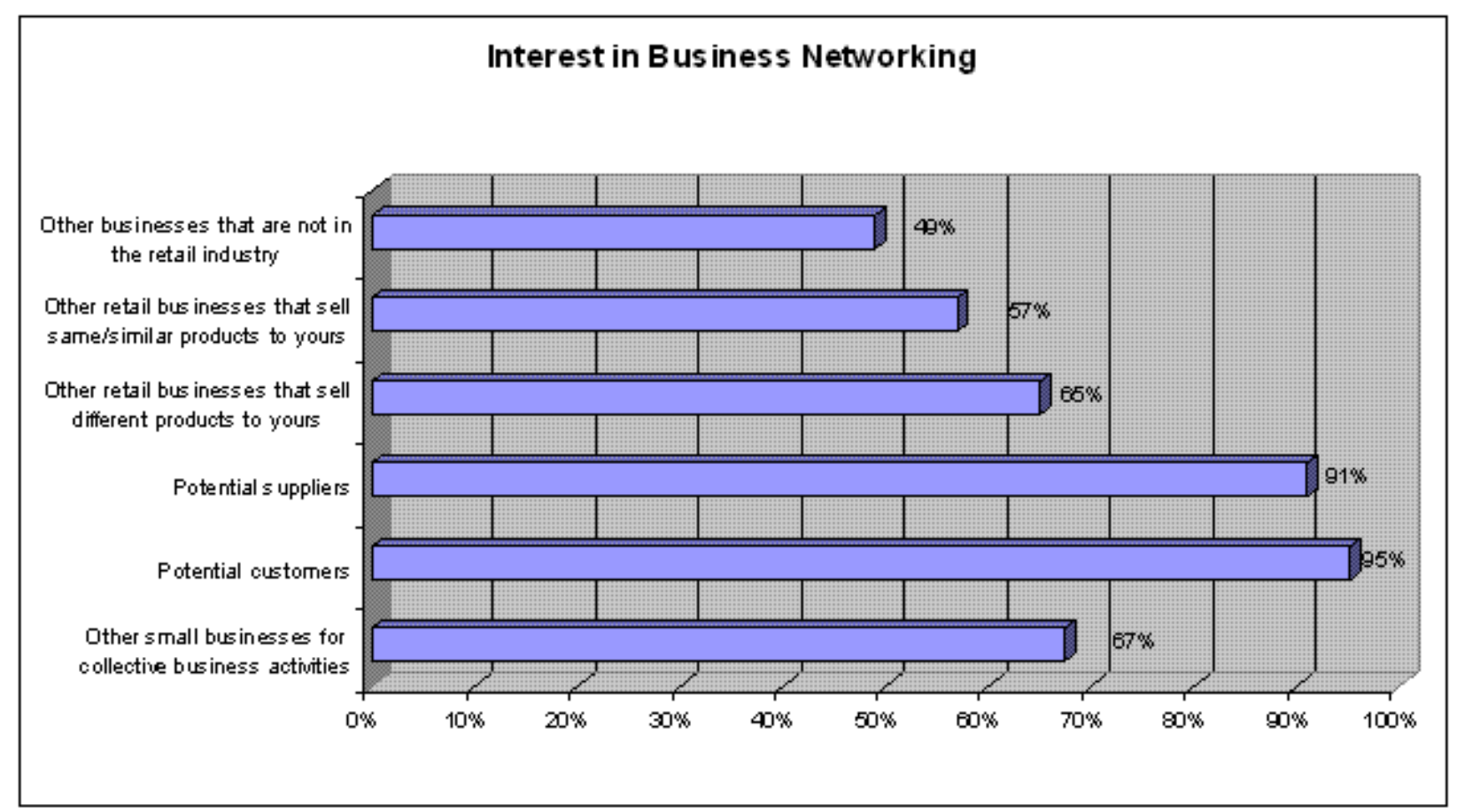

With regard to membership of professional and industrial organisations, most respondents (85\%) did not belong to any such organisations. The biggest reason (40\%) for not joining professional or industrial organisations was that 'I do not know any organisation in my profession/industry'.

It is important to note that $39 \%$ of the respondents believed that 'these organisations [did] not offer any value to my business'. In addition, 33\% did 'not want to share my business information'. Smaller percentages of those surveyed indicated that 'these organisation [were] not efficient' (16\%), they had 'had a bad experience with such an organisation' (14\%), or they did 'not want to know other business owners or managers' (8\%).

top

\subsection{Cross tabulation}

When cross-tabulating the results of various questions, some trends in the use of ICTs and attitudes to disclosing information are found:

$\square$ Older businesses had the tendency of not adapting to the use of the Internet (Figure 10): $44 \%$ of the respondents with businesses aged between five and ten years and $36 \%$ of those with businesses over ten years old never accessed the Web from their workplace or accessed it less than once a year.

- In contrast, owners and managers of younger businesses accessed the Web from their workplace more often.

Similar trends are observed in the relationship between the age of the business and access to the Web from home, on the move and from Internet cafés.

Figure 10 Cross tabulation of age of business and frequency of accessing the Web from work 


\section{Business Age \& Accessing Web From Work}

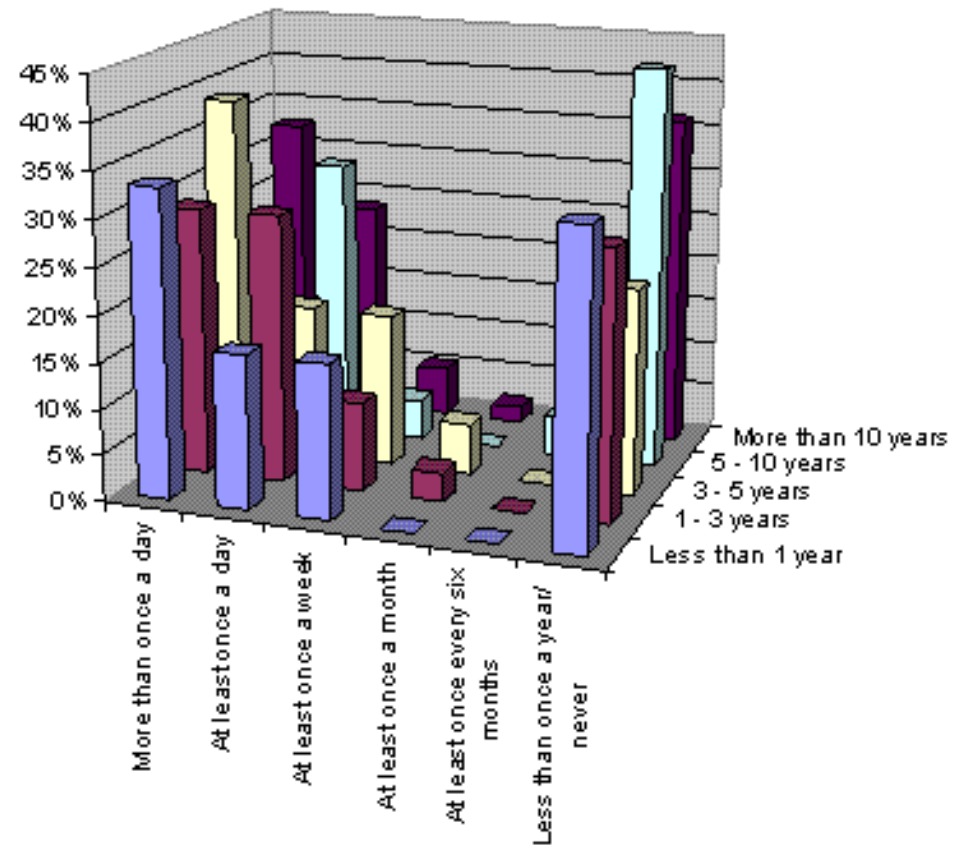

Older businesses also had a tendency of not fully adapting to the use of other ICTs: $42 \%$ of the small businesses over ten years old and $46 \%$ of the businesses between five and ten years old used SMS more than once a week. In contrast, $76 \%$ of the small businesses between three and five years old and $67 \%$ of businesses less than one year old used this service regularly.

A very similar trend is observed in the relationship between the age of the business and the use of e-mail (Figure 11). In fact, similar trends are also found in businesses' adaptation to other ICTs including RSS, blogging, podcasting, wikis, VolP, message board, instant messenger, newsgroups, chat rooms and multimedia short message (MMS).

Figure 11 Cross tabulation of age of business and e-mail usage

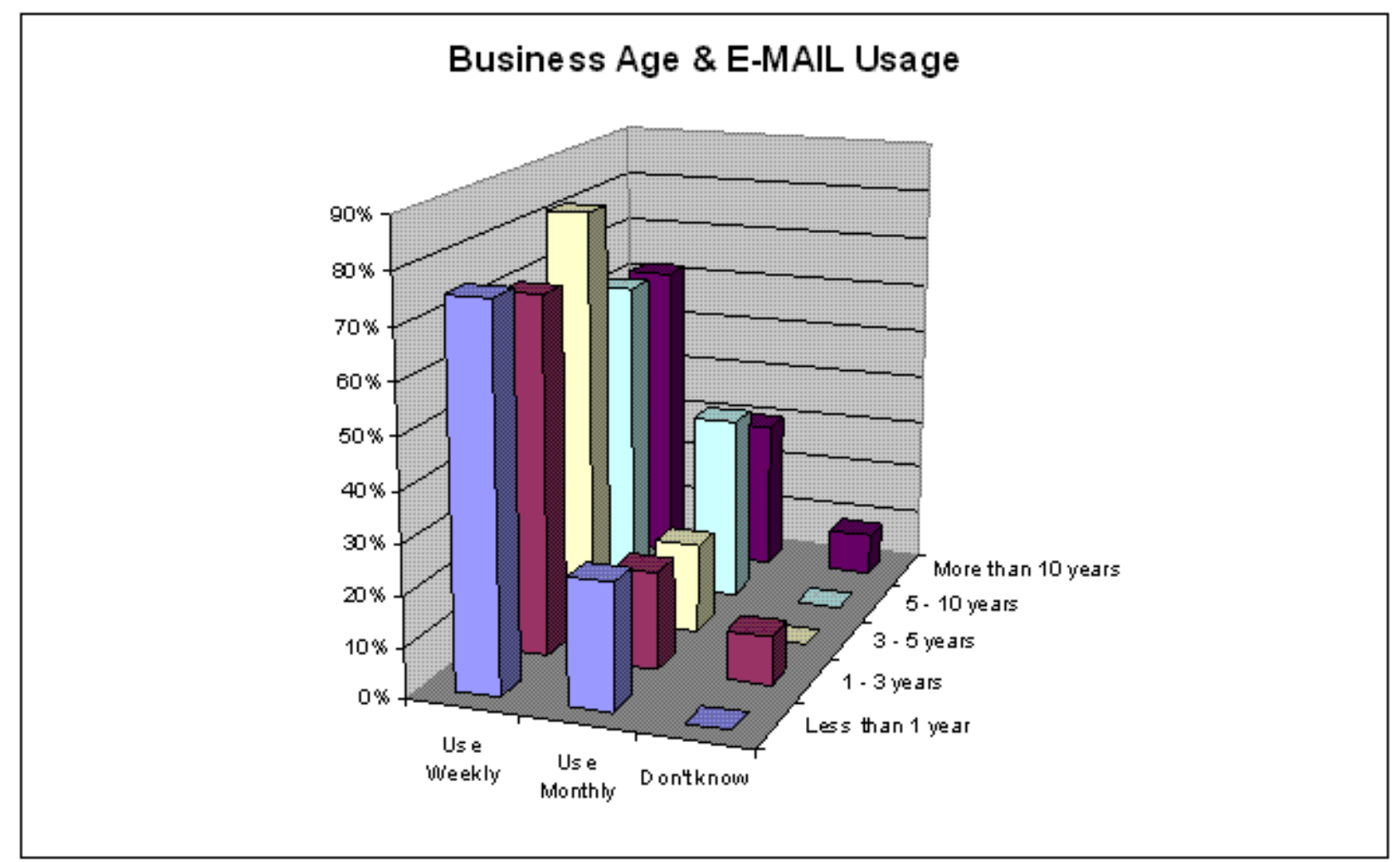


It is surprising that small businesses with a higher turnover adopted ICTs less ardently. A hundred per cent of businesses with an average annual turnover of between 100000 and 200000 rand used e-mail weekly, in contrast to $54 \%$ of the businesses with an average turnover of over 3 million rand, which used e-mail weekly. Similar trends can be observed in the relationships between turnover and usage of other ICTs.

There was no significant relationship between the age of a business and attitudes to the disclosure of business information. Most respondents were not willing to disclose their business information, especially finance and sales figures (Figure 12). Their attitudes were mixed for disclosing other nonfinance related business information, such as suppliers' information (Figure 13). Similar trends could be observed in their attitudes to disclosing other internal and external business information.

It is noticed that new small businesses (less than a year old) were the most unwilling to disclosing any business information: $71 \%$ of the businesses that had been in operation for less than a year would disclose their supplier information to 'no extent' as compared to $19 \%$ of the businesses between one and three years old, $29 \%$ of the businesses between three and five years old, $33 \%$ of the businesses between five and ten years old and $28 \%$ of the businesses over ten years old.

Figure 12 Cross tabulation of age of business and share of sales figure information

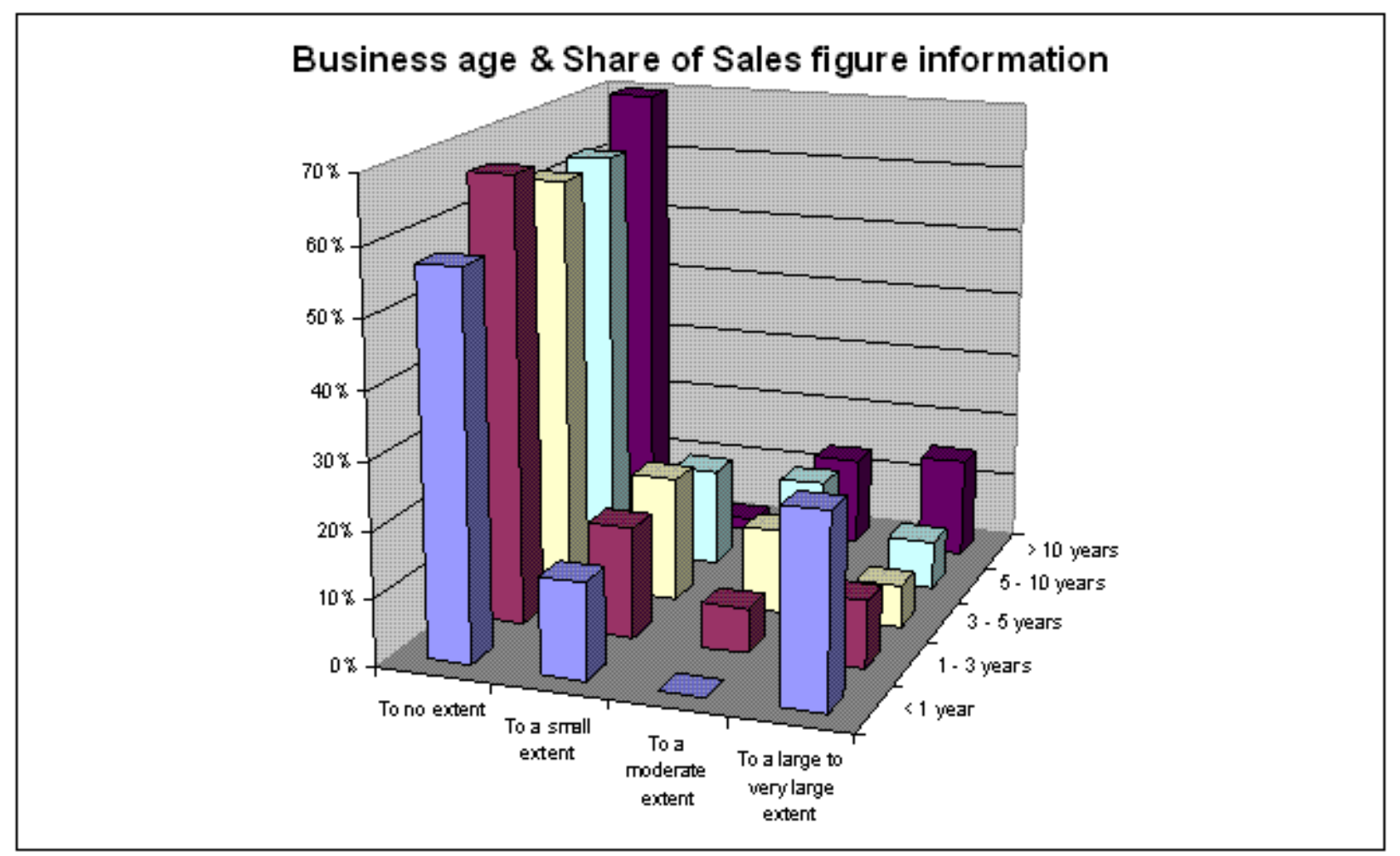

Figure 13 Cross tabulation of age of business and willingness to share supplier information 


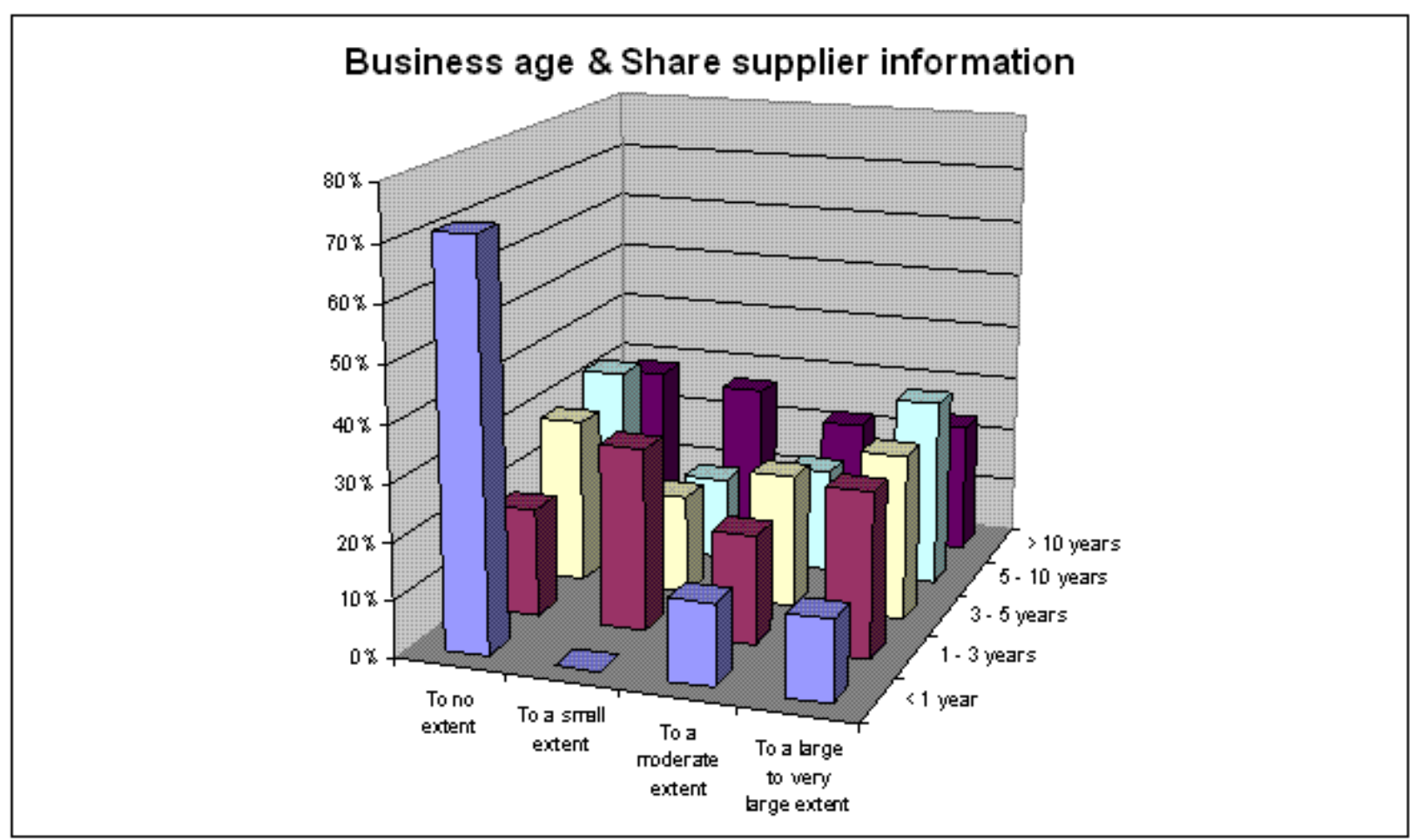

Sales figures and finance were the most sensitive information to small business owners and managers. Regardless of the levels of turnover of their businesses, owners and managers tend not to disclose their sale figures or finance information (Figure 14). The attitudes were mixed for nonfinancial business information.

Figure 14 Cross tabulation of average annual turnover and share of sales figure information

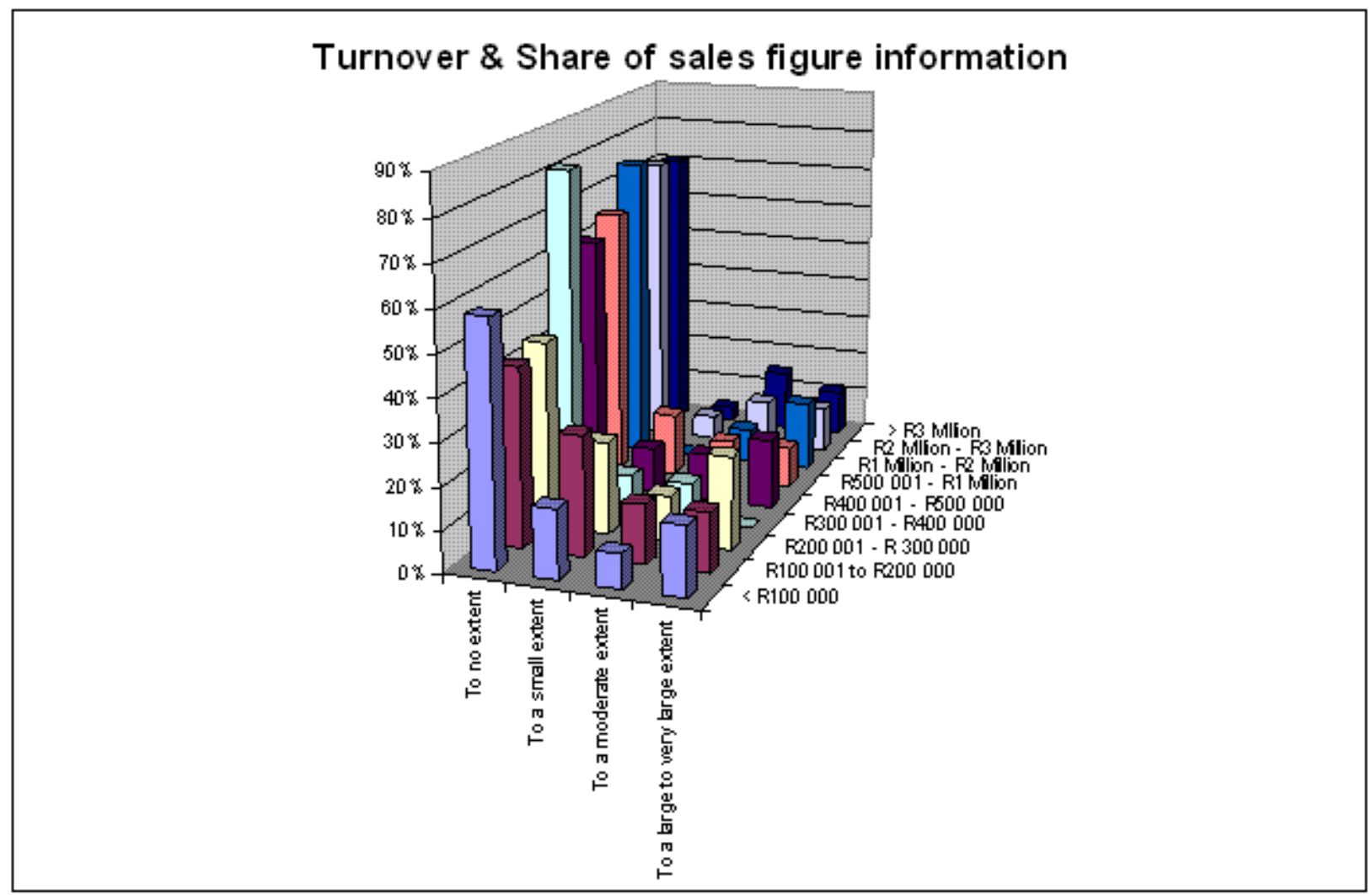

\section{Conclusion}


The findings from the research are significant in that it provides a better understanding for stakeholders in small business development in South Africa.

In terms of the survey's business biographical information, textiles, clothing, footwear and leather goods were the most popular areas of trade and nearly all respondents preferred English for business communication. Small businesses were typically owner-managed with a small number of employees.

Small business development agencies were not well known to small business owners and managers, and the rate of use was even lower. However, respondents showed high interest in access to more information, especially access to finance and business development services.

In ICT usage, the infrastructure was in place for small businesses, but use was still limited.

Traditional media such as television, radio, printed newspapers and magazines were still the primary sources of information. For community and portal activities, small business owners and managers were unwilling to disclose business information, especially their financial information. However, they were very interested in networking with other businesses, in particular with potential customers and suppliers. Most small businesses did not belong to any professional organisations, primarily because they did not know of such organisations in their professions or industries.

These are some of the factors that need to be considered when promoting the use of information resources to small businesses in South Africa.

top

\section{References}

Baumol, W.J. 2006. Entrepreneurship and small business: toward a program of research. Foundation and Trends in Entrepreneurship 2(3):155.

Bogdanowicz, M.S. and Bailey, E.K. 2002. The value of knowledge and the values of the new knowledge worker: generation $\mathrm{X}$ in the new economy. Journal of European Industrial Training 26 $(2 / 3 / 4): 125-129$.

Chen, H-J. and Rensleigh, C. 2008. Web portals for the improved use of digital information resources in South African small businesses, 10 ${ }^{\text {th }}$ Annual Conference on WWW Applications, September 2008. Cape Town.

De Bruyn, H.E.C. 2003. Strategic management: a Southern African perspective. Johannesburg: Entrepro Publishers.

Kubheka, B. 2006. Small business survey highlights 2006. Johannesburg: African Response.

Statistics South Africa. 2003. General household survey 2003. Pretoria: Statistics South Africa.

Stokes, D. 1997. Pasteur's quadrant: basic science and technological innovation. Washington: Brookings Institution Press.

Uzokwelu, C.J. and Gunnarsdottir, L.A. 2001. What roles do virtual communities play in the new economy? Copenhagen: IT University of Copenhagen.

Womack, J.P. and Jones, D.T. 2005. Lean consumption. Harvard Business Review. [Online]. Available WWW: http:/ / custom.hbsp.com/ b01/ en/ implicit/ custom.j html? pr=LEANER0503C2005030462 (Accessed 24 April 2009). 